\title{
PREPARATION AND BIOLOGICAL PROPERTIES OF A CHEMICALLY MODIFIED ESCHERICHIA COLI ENDOTOXIN OF HIGH IMMUNOGENIC POTENCY AND LOW TOXICITY
}

\author{
By HANS NOLL * AND ABRAHAM I. BRAUDE $\dagger$ \\ (From the Department of Microbiology and the Department of Medicine, School of Medicine, \\ University of Pittsburgh, Pa.)
}

(Submitted for publication February 27, 1961 ; accepted June 29, 1961)

The chemical basis of the toxic and immunogenic properties of endotoxins from enteric gramnegative bacilli has been the subject of intensive investigation. Recent methods of purification yielded biologically active preparations which were essentially free of dissociable protein and consisted of complex phosphorylated lipopolysaccharides containing firmly bound peptides $(1,2)$. Chemical degradation destroyed toxicity, liberating complex phosphoglycolipds and a haptenic polysaccharide endowed with serological specificity (1, 3-7). It was concluded that the lipid was essential for toxicity, whereas the polysaccharide merely functioned as a water-soluble carrier ( 7 , $8)$. This concept was supported by the successful restoration of toxicity upon artificial recombination of the lipid with unrelated proteins $(9,10)$.

These findings suggested the possibility of preparing a nontoxic antigen by chemical dissociation of the lipid from the native endotoxin complex. In the past, all attempts to separate the toxic from the antigenic properties failed, since the hydrolytic methods employed lacked the required selectivity and invariably destroyed the antigenic properties more rapidly than the toxicity $(1,2)$. The use of nonhydrolytic reagents of greater specificity, on the other hand, appeared to offer a more promising approach. In the present study, the selective reduction of toxicity was accomplished by the treatment of a Boivin antigen from Escherichia coli with $\mathrm{LiAlH}_{4}$. The data presented show that the resulting product retained the immunogenic potency and serologic activity of the original complex.

\footnotetext{
* Supported by Research Grant E-1500 from the Division of Research Grants of the National Institutes of Health, and by Senior Research Fellowship SF-274 from the Public Health Service.

$\dagger$ Supported by the Research and Development Division, Office of the Surgeon General, Dept. of the Army, Washington, D. C.
}

The choice of $\mathrm{LiAlH}_{4}$ was suggested by earlier studies on the chemical structure of mycobacterial glycolipids. It has been shown that the fatty acids of these lipids are frequently linked to the carbohydrate portion through ester bonds which are reductively cleaved by $\mathrm{LiAlH}_{4}$ without damage to the carbohydrate moiety (11-16).

\section{MATERIALS AND METHODS}

Reagents. $\mathrm{LiAlH}_{4}$ and $\mathrm{NaBH}_{4}$ were purchased from Metalhydrides, Inc. Pyrogen-free saline and distilled water were obtained from the Abbott Company.

Decontamination. Equipment (glassware, needles, and so on) was made free of pyrogen by heating at $170^{\circ} \mathrm{C}$ for 2 hours. Plastic material and other equipment that could not be exposed to this temperature were made pyrogenfree by immersion in 10 per cent $\mathrm{NaOH}$ for at least 2 hours and rinsed with pyrogen-free distilled water.

Bacterial cultures. E. coli of serotype $0: 113$, isolated from the blood of a patient, was subcultured on agar containing 5 per cent rabbit blood.

Media. For large scale growth, a synthetic salt medium, containing glucose as carbon and $\mathrm{NH}_{4}^{+}$as nitrogen source, was used (17).

Preparation of endotoxin. The bacteria were grown in 12.5-L batches as described previously (17). Growth was stopped after 18 hours by the addition of $75 \mathrm{ml}$ of a 40 per cent formalin solution. The cultures were harvested with a DeLaval gyro-test unit, washed with 95 per cent ethanol, followed by acetone, and dried in a vacuum oven at $56^{\circ} \mathrm{C}$. The bacterial mass, suspended in 5 parts of distilled water with a Waring Blendor, was incubated at $60^{\circ} \mathrm{C}$ for 90 minutes and subsequently at $4^{\circ}$ overnight. An equal volume of cold $1.25 \mathrm{M} \mathrm{CCl}_{3} \mathrm{COOH}$ was added with short mixing in a Blendor and the suspension kept at $4^{\circ} \mathrm{C}$ for 3 hours. The extract was separated by centrifugation at $12,000 \mathrm{rpm}$ at $5^{\circ} \mathrm{C}$, dialyzed for 48 hours against running distilled water, passed through a Seitz filter, and precipitated by the addition of 95 per cent ethanol to a final concentration of 68 per cent by weight. After 12 hours at $4^{\circ} \mathrm{C}$, the precipitated endotoxin was collected, washed with 95 per cent ethanol followed by ether, dried in vacuo to constant weight, and stored over a desiccant. The endotoxin was obtained as a white powder in a yield of about 5 per cent based on the bacterial dry weight. 
Chemical and spectroscopic assays. Carbohydrate was determined by the phenol-sulfuric acid method (18). Reference samples of glucose and endotoxin standard solutions were included in each assay. Fatty acid esters were determined by the method of Snyder and Stephens (19), as modified for endotoxins by Tauber (20). Crystalline tripalmitin served as standard.

Infrared spectra were recorded with a Beckman IR-4 double-beam spectrophotometer. The samples were prepared by the $\mathrm{KBr}$ micropellet technique as described previously (21).

\section{Chemical treatment of endotoxin}

Reduction with $\mathrm{LiAlH}_{4}$. In a first experiment, a suspension of $300 \mathrm{mg}$ of endotoxin in $30 \mathrm{ml}$ of dry ether was refluxed for 5 hours. A total of $150 \mathrm{mg}$ of $\mathrm{LiAlH}_{4}$ was added in $10-\mathrm{mg}$ portions at regular intervals. Excess reagent and the $\mathrm{LiAl}$ alkoxide addition products of the reaction were decomposed by careful addition of moist ether followed by $50 \mathrm{ml}$ of water. Pyrogen-free distilled water was used throughout. The ether was separated and the aqueous phase re-extracted twice with $50-\mathrm{ml}$ portions of ether. After drying over anhydrous $\mathrm{Na}_{2} \mathrm{SO}_{4}$, the pooled ether extracts were taken to dryness in vacuo, yielding $5 \mathrm{mg}$ of a lipid residue. The insoluble $\mathrm{Al}(\mathrm{OH})_{3}$ was removed from the aqueous phase by filtration and washed with water. The clear filtrate, after dialysis against water overnight and lyophilization, yielded $38 \mathrm{mg}$ (13 per cent of the original starting material) of a white fluffy residue, designated "reduced endotoxin I" (RE I). The remaining major portion of endotoxin was firmly adsorbed to the aluminum hydroxide gel, since a carbohydrate assay of the resuspended precipitate accounted for the balance.

In a second experiment, the reaction mixture was immediately neutralized to $\mathrm{pH} 7$ at the end of the reduction period in order to minimize the possibility of alkaline hydrolysis during the isolation of the water-soluble product. Thus, $50 \mathrm{mg}$ of endotoxin in ether was refluxed with $100 \mathrm{mg}$ of $\mathrm{LiAlH}_{4}$ for 5.5 hours. The mixture was then decomposed by the addition of $3.1 \mathrm{ml} 1 \mathrm{~N} \mathrm{HCl}$. After removal of the ether phase, the aqueous suspension was diluted to a volume of $20 \mathrm{ml}$ and filtered through a fritted glass funnel of medium porosity. The filtrate contained $3.3 \mathrm{mg}$ of reaction product, as determined by carbohydrate assay. It was deionized by passage through a column of Amberlite MB-3 mixed-bed resin which had been thoroughly washed with pyrogen-free distilled water. The lyophilized effluent yielded $3 \mathrm{mg}$ residue, designated RE II.

Alkaline hydrolysis with LiOH. An aqueous solution

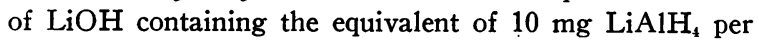
$\mathrm{ml}$ was prepared by decomposition of the hydride with water and filtration of the insoluble alumina gel. A series of tubes containing $50 \mathrm{mg}$ of endotoxin and increasing amounts of $\mathrm{LiOH}$ in a total volume of $10 \mathrm{ml}$ was allowed to stand at $20^{\circ} \mathrm{C}$. The reaction was stopped by neutralization with the strongly acidic cation exchanger Amberlite IR $120\left(\mathrm{H}^{+}\right.$form $)$and the product isolated by lyophilization. The resin was made pyrogen-free by previous treatment with 10 per cent $\mathrm{NaOH}$ followed by regeneration with $2 \mathrm{~N} \mathrm{HCl}$ and extensive washing with pyrogen-free water.

Alkaline hydrolysis with $\mathrm{NaOH}$. The preparation of $\mathrm{NaOH}$-treated endotoxin is described below under "Antibody titrations by hemagglutination."

\section{Bioassays}

Pyrogenicity. The pyrogenic effect of the test preparations was measured rectally after injection into the marginal ear vein of carefully conditioned albino rabbits weighing 3 to $5 \mathrm{~kg}$. Temperatures were recorded hourly for 8-hour periods prior to and after injection of the test materials. The experimental techniques and equipment used have been described in detail (22). Pyrogenic potency was measured by plotting the maximal temperature rise caused by endotoxin doses ranging from 0.0001 to $1.0 \mu \mathrm{g}$ against the logarithm of the dose. The minimal pyrogenic dose, defined as the amount required to produce a $1.0^{\circ} \mathrm{F}\left(0.56^{\circ} \mathrm{C}\right)$ rise, was determined from the resulting linear log dose-response curve and gave a value of $0.00045 \mu \mathrm{g}$ for the standard endotoxin preparation used in these experiments.

Lethal toxicity. Litter mates of white Swiss mice obtained from Flora O'Grady were injected into the tail veins with twofold dilutions of the test preparations. Groups of 5 mice were used for each dose and the toxicity expressed as the fraction of survivors after 72 hours. The $L D_{50}$ was calculated by probit analysis according to Finney (23) in those cases where the data required a statistical test of significance.

Hematology. Hematologic changes were studied by total and differential leukocyte counts in duplicate on blood obtained from rabbits by nicking the central artery of the ear at zero time, 5 minutes, 1 hour and 4 hours.

Antibody titrations by hemagglutination. The concentration of antibodies against endotoxin preparations was determined by hemagglutination essentially as described by Neter and co-workers (24). One $\mathrm{ml}$ of saline containing $10.0 \mathrm{mg}$ of endotoxin was added to $4.5 \mathrm{ml} 0.25$ $\mathrm{N} \mathrm{NaOH}$ and incubated at $37^{\circ} \mathrm{C}$ for 3 hours. After neutralization with $4.5 \mathrm{ml} 0.25 \mathrm{~N} \mathrm{HCl}, 1.0 \mathrm{ml}$ of packed human group $\mathrm{O}$ erythrocytes was added and the suspension incubated for 1 hour at $37^{\circ} \mathrm{C}$. The red cells had previously been washed 4 times with saline. The sensitized red cells were separated by centrifugation, washed 3 times with saline and resuspended to a concentration of 2.5 per cent. Sera were inactivated by incubation in a water bath for 30 minutes at $56^{\circ} \mathrm{C}$, absorbed with group $\mathrm{O}$ human cells to remove red cell agglutinins and diluted serially by adding $0.5 \mathrm{ml}$ to $0.5 \mathrm{ml}$ of saline. To each tube containing $0.5 \mathrm{ml}$ of serially diluted serum was added $0.1 \mathrm{ml}$ of the sensitized cell suspension and the mixtures incubated at $37^{\circ} \mathrm{C}$ for 60 minutes. After overnight refrigeration at $4^{\circ} \mathrm{C}$, the tubes were shaken and the agglutination endpoint was determined by visual inspection of the state of dispersion of the red cell suspensions. 


\section{Antigcnic analysis by precipitin reactions in agar}

Precipitin reactions in agar were carried out by the diffusion technique of Ouchterlony (25) with sera of rats immunized with various endotoxin preparations.

Immunization of rats. Holtzman albino rats, weighing approximately $365 \mathrm{~g}$, were divided into 5 groups and immunized according to the schedule in Table I. Two to $3 \mathrm{ml}$ of blood was obtained by cardiac puncture at 4,8 , 15 and 30 days after the final injection. The blood was drawn from 2 rats each time in the first 3 groups and from 3 rats in the latter 2 groups.

Preparation of agar plates. Agar diffusion plates were prepared essentially as described by Halbert, Swick and Sonn (26). A solution of $0.7 \mathrm{~g}$ of Bacto-agar (Difco) in $100 \mathrm{ml}$ boiling saline was mixed, after cooking, with $0.8 \mathrm{~g}$ sodium barbital and $7.5 \mathrm{~g}$ glycine and the $\mathrm{pH}$ adjusted to 7.4 with $0.1 \mathrm{~N} \mathrm{HCl}$. Eight $\mathrm{ml}$ molten agar was poured into petri dishes measuring $60 \times 20 \mathrm{~mm}$ and allowed to solidify about a mold with one center and six outer holes of $8 \mathrm{~mm}$ diameter. The mold was removed from the hardened agar and the plates stored at $4^{\circ} \mathrm{C}$ for 1 to 4 days, allowing excess fluid to seep into the wells whence it could be removed by suction.

In one group of experiments, the test was performed by placing $0.2 \mathrm{ml}$ antigen solution containing $200 \mu \mathrm{g}$ of the test preparation in the center well and $0.2 \mathrm{ml}$ of serum in the outer wells; in other experiments, various antigens were pipetted into the outer wells and the antiserum into the center well. Plates were incubated in the refrigerator and examined for precipitation bands 48 hours later and daily thereafter.

Immunization against E. coli-induced pyelonephritis in rats

Twenty male albino rats of the Holtzman strain, weighing about $365 \mathrm{~g}$, were injected intraperitoneally with 1.0 $\mu \mathrm{g} \mathrm{LiAlH} \mathrm{H}_{4}$-treated endotoxin ( $\mathrm{RE} \mathrm{I}$ ) and $2.0 \mathrm{ml}$ blood was collected by cardiac puncture 7 days later from each of 5 rats. Since no hemagglutinating antibodies were detected, all rats were given a second injection of $19 \mu \mathrm{g}$ of the same antigen and cardiac blood was drawn again from the previously bled 5 rats 7 days after the second injection. Antibody titers had risen sharply to titers rang-

TABLE I

Immunization schedule of rats for antigenic analysis

\begin{tabular}{|c|c|c|c|c|}
\hline Group & $\begin{array}{l}\text { No. } \\
\text { of rats }\end{array}$ & Antigen & Amount & Route \\
\hline 1 & 6 & $\begin{array}{l}\text { Untreated Boivin endo- } \\
\text { toxin }\end{array}$ & $20 \mu g^{*}$ & i.p. \\
\hline 2 & 6 & $\begin{array}{l}\text { Reduced endotoxin, } \\
\text { prep. RE I }\end{array}$ & $20 \mu g^{*}$ & i.p. \\
\hline 3 & 6 & $\mathrm{NaOH}$-treated endotoxin & $20 \mu \mathrm{g}^{*}$ & i.p. \\
\hline 4 & 12 & $\begin{array}{l}\text { 18-hour broth culture } \\
\text { of heat-killed } \dagger E \text {. coli }\end{array}$ & $0.5 \mathrm{ml}$ & i.c. \\
\hline 5 & 12 & $\begin{array}{l}\text { 18-hour broth culture } \\
\text { of viable } E . \text { coli }\end{array}$ & $0.5 \mathrm{ml}_{+}^{+}$ & i.c. $\$$ \\
\hline
\end{tabular}

* Two injections at 1 -week interval.

$+80^{\circ} \mathrm{C}$ for 60 minutes.

$10^{9}$ Bacteria per ml.
Intraca rdial injection followed by renal massage.

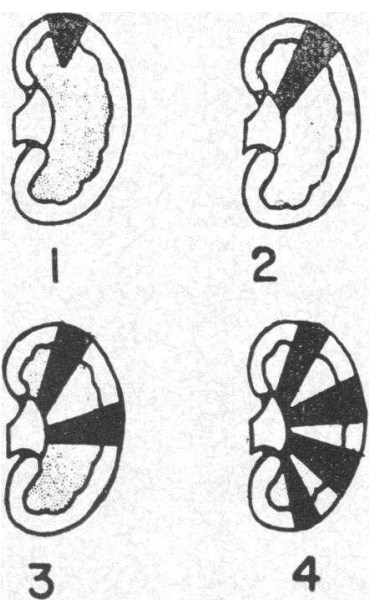

\section{GRADE OF SEVERITY}

Fig. 1. Quantitative estimation of Severity of PYELONEPhRITIS. Progressive stages are graded 1 to 4 as shown by the schematic drawings.

ing from $1: 32$ to $1: 256$. Ten days after injection of the second antigen dose, $2 \mathrm{ml}$ of cardiac blood was drawn from all of the 20 immunized rats and from 20 nonimmunized controls. Immediately afterward, each rat was inoculated intracardially with $0.5 \mathrm{ml}$ of an 18-hour culture in trypticase soy broth containing approximately $10^{\circ}$ cells per $\mathrm{ml}$ of the same $E$. coli strain from which the endotoxin had been extracted. The kidneys of the animals were massaged for 5 minutes through the intact abdominal wall in order to produce pyelonephritis (27). Seven days later all surviving rats were sacrificed by exsanguination and exposure to ether. Their kidneys were examined for the pathological changes of pyelonephritis and the severity of the disease graded according to the system illustrated in Figure 1. Each kidney was then weighed and ground to a pulp in a homogenizing tube with a Teflon-tipped, motor-driven, stainless steel pestle. The individual homogenates were diluted serially in steps of 1:10 with water and pour plates made of each dilution. After incubation at $37^{\circ}$ for 24 hours, the total number of viable bacteria per gram of tissue was calculated for each kidney from the colony counts.

\section{RESULTS}

Physicochemical characterization of endotoxin preparations. It is well known that the chemical composition of endotoxin preparations varies considerably, depending upon the method of isolation, but under carefully standardized conditions, materials of fairly constant nitrogen, carbohydrate and lipid content are obtained. The Boivin type lipopolysaccharide-protein complexes, extracted with trichloroacetic acid and characterized by a 
relatively high nitrogen content ( 2 to 4 per cent), are both toxic and immunogenic. Preparations of equal toxicity, but lower nitrogen content (1.0 to 1.5 per cent), have been obtained by various extraction and purification procedures, sometimes with loss of immunogenicity $(1,2,9,28,29)$. Since the primary objective of this study was to reduce the toxicity of highly antigenic preparations rather than to purify for increased toxicity, a Boivin type endotoxin was used without further purification.

For the analytical characterization of the endotoxin preparations under study, quantitative infrared spectrophotometry and a sensitive colorimetric assay for carbohydrate (18) were used. Infrared spectroscopy has proved to be a most powerful analytical tool in investigations of complex lipids, particularly for a preliminary characterization of preparations of unknown purity and chemical structure $(15,16,30)$. Webster, Sagin, Landy and Johnson have published infrared spectra of a Boivin antigen, a protein-free lipopolysaccharide, and degraded polysaccharide (hapten) which clearly show that the proportions of protein, carbohydrate and lipid in these preparations are reflected in the appearance and relative intensity of characteristic absorption bands (1).

The infrared spectrum of the Boivin antigen used in these studies (Figures 2, 4, 5) was highly reproducible from one batch to another and similar to the spectrum published by Webster and coworkers. The carbohydrate content (expressed as glucose equivalents) was constant within \pm 5 per cent and corresponded to 32.5 per cent of the dry weight. Acid hydrolysis with constant boiling aqueous $\mathrm{HCl}$ in an atmosphere of nitrogen resulted in the maximal liberation of 4 per cent of $-\mathrm{NH}_{2}$ after 90 minutes. Before hydrolysis, the content of free amino groups in endotoxin was 0.3 per cent. as determined with ninhydrin (31).

Effect of reduction with $\mathrm{LiAlH}_{4}$ on chemical structure and biological properties of endotoxin. Treatment of endotoxin with an excess of $\mathrm{LiAlH}_{4}$ gave a water-soluble reaction product and a small amount of an ether-soluble lipid. The watersoluble reaction product was a white powder which formed opalescent solutions in water. The carbohydrate content remained virtually unchanged, corresponding to 33.3 per cent before and 32.7 per cent after treatment.
The spectra of the original endotoxin and of the ether- and water-soluble reaction products are reproduced in Figure 2. The spectrum of the ether-soluble lipid (Figure $2 \mathrm{~b}$ ) shows the characteristic absorptions of a long chain aliphatic alcohol (15). Since ether-soluble long chain aliphatic alcohols have never been found in hydrolysates of endotoxin, they must have been derived from the corresponding fatty acids as a result of the reductive cleavage of ester bonds which originally linked the fatty acids to the carbohydrate or peptide moiety of the endotoxin. This conclusion is also supported by a spectral comparison of the watersoluble reaction product $\mathrm{RE} I$ with untreated endotoxin (Figure 2a). The most conspicuous changes are the decrease in the $\mathrm{CH}$ stretching absorptions near $2,900 \mathrm{~cm}^{-1}$ and the virtual disappearance of the $\mathrm{CO}$ stretching bands near 1.735 $(\mathrm{C}=\mathrm{O})$ and $1,250(\mathrm{C}-\mathrm{O}) \mathrm{cm}^{-1}$ in the spectrum of the water-soluble reaction product. No satisfactory explanation has been found for the appearance of a strong new band at $1,420 \mathrm{~cm}^{-1}$. In the region of the strong carbohydrate absorptions between 1,100 and $1,000 \mathrm{~cm}^{-1}$, the originally only faintly resolved band separates into two distinct peaks at 1,090 and $1,050 \mathrm{~cm}^{-1}$ after treatment. This effect may be explained by the elimination of a strong absorption band near $1,060 \mathrm{~cm}^{-1}$, possibly due to the removal of organic phosphate, which is known to absorb strongly in this region. Significant modification of the carbohydrate moiety seems unlikely, since both carbohydrate content and the associated serological activity remained unchanged after treatment with $\mathrm{LiAlH}_{4}$.

Biological properties. a) Toxicity. As is evident from the chart in Figure 3, intravenous injections of reduced endotoxin produced no fever or other signs of illness in rabbits, even in the highest dose of $100 \mu \mathrm{g}$ tested. In contrast, the minimal pyrogenic dose of untreated endotoxin was 0.00045 $\mu \mathrm{g}$, and doses of $5 \mu \mathrm{g}$ were frequently lethal. Thus, treatment with $\mathrm{LiAlH}_{4}$ reduced the pyrogenicity of endotoxin by a factor of at least $10^{5}$.

The results of a toxicity assay in mice are shown in Table II. Intravenous injections of $1.0 \mathrm{mg}$ of $\mathrm{LiAlH}_{4}$-treated endotoxin failed to cause a significant lethal effect, but the available material was insufficient to permit an $\mathrm{LD}_{50}$ determination. In contrast. the $\mathrm{LD}_{50}$ of the original endotoxin was $0.10 \mathrm{mg}$. 


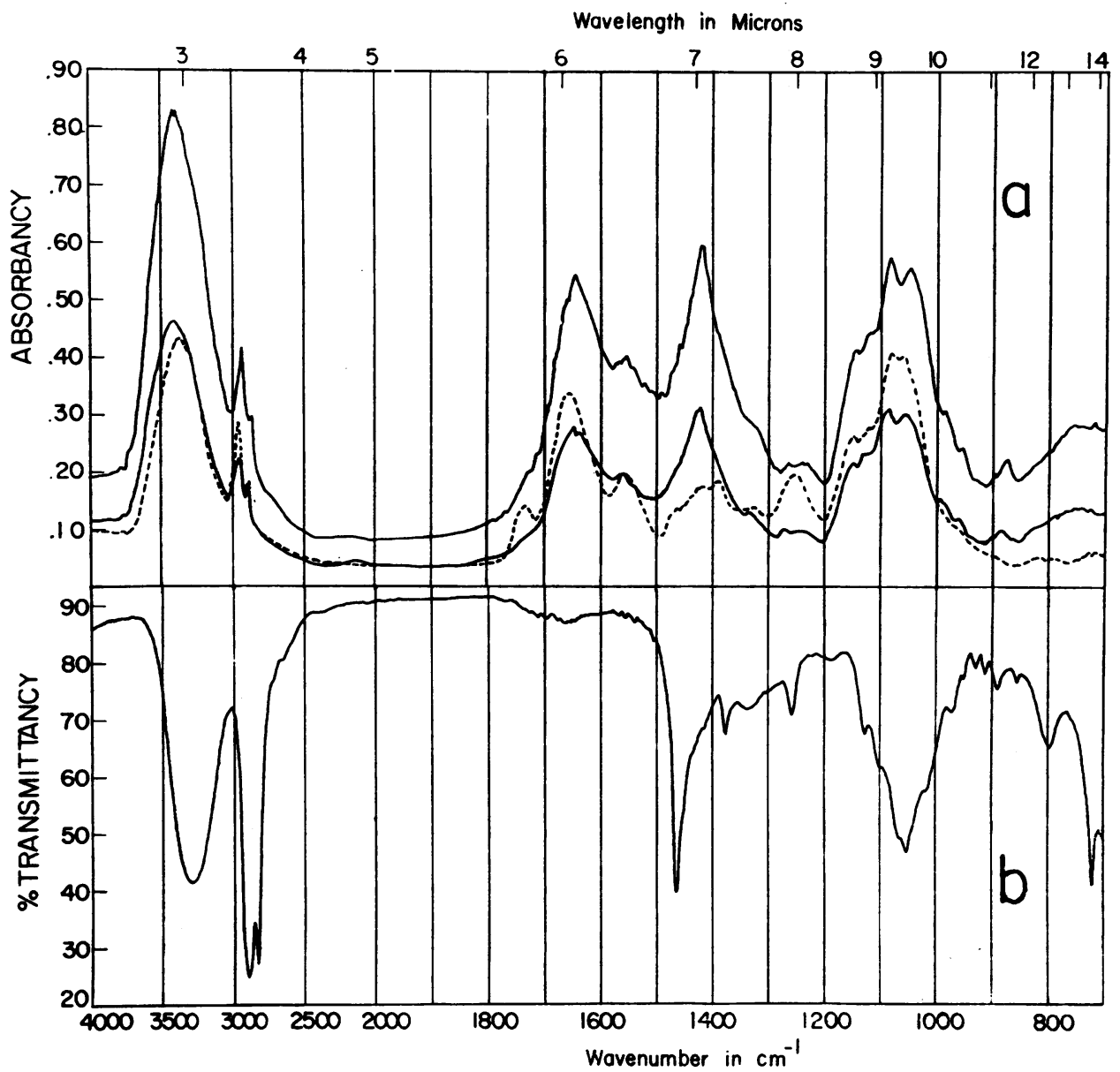

Fig. 2. EfFect of LiAlH, treatMent on INFraRed SPECtra of endotoxin. a) Broken curve: untreated Boivin antigen, $27 \mu \mathrm{g}$ per $4.3 \mathrm{mg} \mathrm{KBr}$; solid curves : upper, nondialyzable water-soluble reaction product ( $\mathrm{RE} \mathrm{I}$ ), $36 \mu \mathrm{g}$ per $5.0 \mathrm{mg} \mathrm{KBr}$; lower, $27 \mu \mathrm{g}$ per $4.3 \mathrm{mg} \mathrm{KBr}$. b) Ether-soluble reaction product (melt).

No significant change was observed in the leukacyte count of three rabbits during a 4-hour period after the intravenous injection of $5.0 \mu \mathrm{g}$ of the ester-free endotoxin. Injection of the same

TABLE II

Lethality for mice of reduced and original endotoxin

\begin{tabular}{ccc}
\hline & \multicolumn{2}{c}{ Fraction dead after 72 hours } \\
\cline { 2 - 3 } Preparation & RE I & $\begin{array}{c}\text { Orig. } \\
\text { endotoxin }\end{array}$ \\
\hline$m g$ inj. & & \\
0.063 & $0 / 5$ & $4 / 10$ \\
0.125 & $0 / 5$ & $4 / 10$ \\
0.25 & $0 / 5$ & $10 / 10$ \\
0.50 & $1 / 5$ & $10 / 10$ \\
1.00 & $1 / 5$ & $10 / 10$ \\
LD $_{50} \mathrm{mg}$ & $\gg 1.0$ & 0.10 \\
\hline
\end{tabular}

amount of untreated endotoxin, on the other hand, produced a sharp neutropenia within 60 minutes, as was evident from the disappearance of 60 to 80 per cent of the neutrophiles from the circulation.

A further manifestation of toxicity is the erythema caused by endotoxin injected into the human skin (32). Three human volunteers were injected intracutaneously with $0.1 \mu \mathrm{g}$ of reduced endotoxin RE II into the right forearm and with an equal dose of regular endotoxin into the left forearm. The $\mathrm{LiAlH}_{4}$-treated preparation caused no visible reaction, whereas all three subjects developed erythema and intense induration at the injection site of the regular endotoxin. This reaction began in 2 hours, reached a maximum in 12 hours and subsided in 48 hours. 
b) Pyrogen tolerance. The results of tolerance studies, illustrated in Figure 3, show that the injection of the nonpyrogenic ester-free endotoxin (RE I, RE II) conferred tolerance to the untreated, pyrogenic parent preparation. The nonpyrogenic endotoxin was given according to three different injection schedules. Two groups of three rabbits received six consecutive daily intravenous injections of $1.0 \mu \mathrm{g}(\mathrm{A}-\mathrm{C})$ and $10.0 \mu \mathrm{g}$ (D-F) ; a third group (G-I) received one injection of $100 \mu \mathrm{g}$. Seven days after the first injection, all nine rabbits were challenged simultaneously with six controls by the intravenous injection of $0.5 \mu \mathrm{g}$ untreated endotoxin. All nine rabbits given prior injections of nonpyrogenic endotoxin responded to this challenge with typical, tolerant, monophasic fever curves, while the controls showed the usual biphasic fevers characteristic of the susceptible nontolerant state.

From the hemagglutinin titers recorded in Figure 3 , it can be seen that the production of tolerance with the nonpyrogenic endotoxin was also accompanied by a significant rise in circulating antibodies prior to the date of challenge. It should

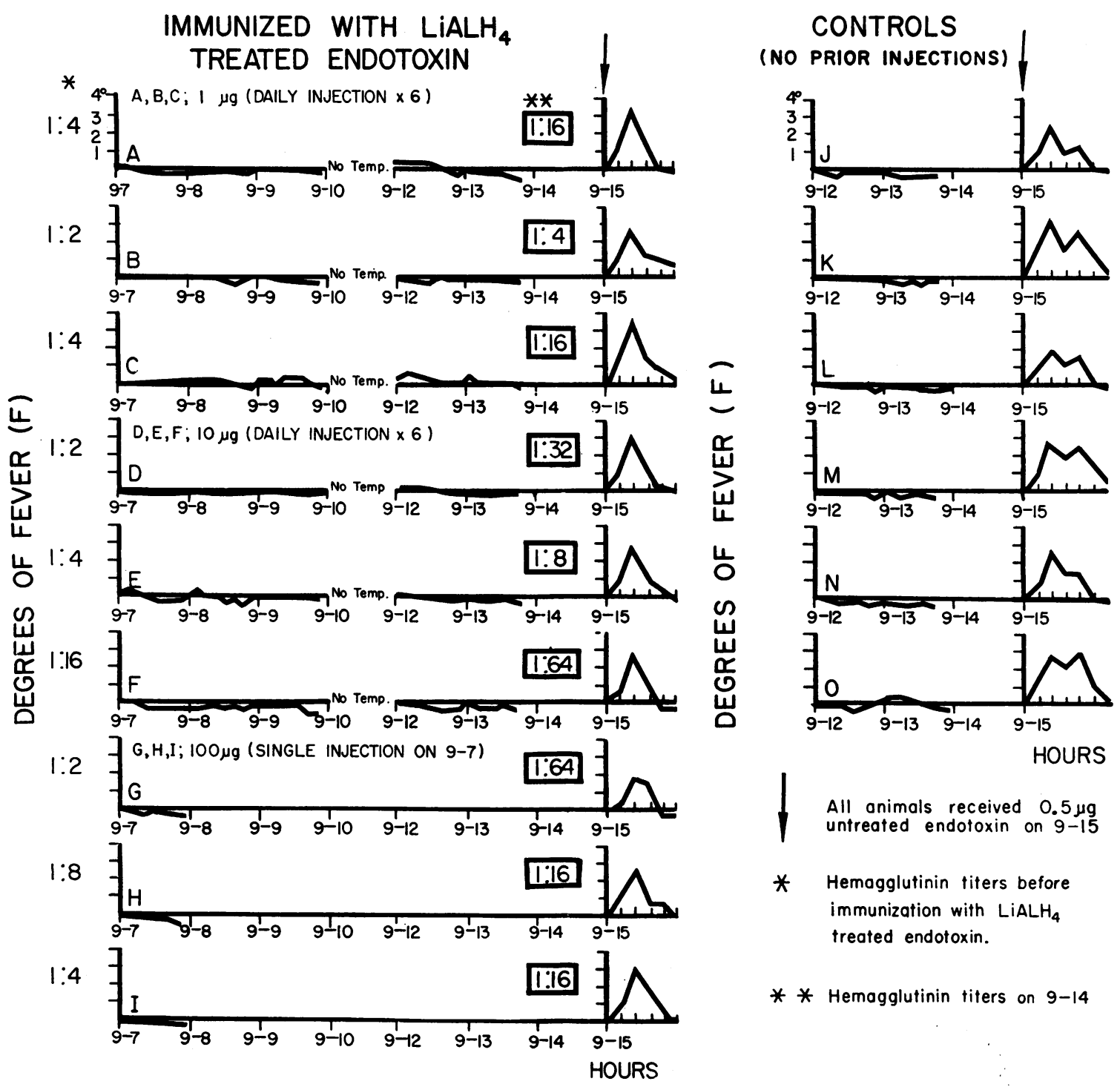

Fig. 3. INDUCTION OF PYROGEN TOLERANCE IN RABBITS WITH NONPYROGENIC ENDOTOXIN PREPARED BY TREATMENT WITH $\mathrm{LIALH}_{4}$. 
be pointed out that these titers reflect the degree of cross reaction with the $\mathrm{NaOH}$-treated antigen required for sensitization of the red cells in this test and hence may not express the true antigenicity of the modified endotoxin for rabbits. The homologous antibody response could not be determined with this technique, since the $\mathrm{LiAlH}_{4}$ treated endotoxin failed to adsorb to the surface of erythrocytes.

c) Tolerance to the lethal effect of endotoxin. 'The injection of nonpyrogenic endotoxin into mice also caused an increased tolerance against the lethal effect of subsequent challenge doses with regular endotoxin. The results obtained with two different preparations of $\mathrm{LiAlH}_{4}$-treated endotoxin, listed in Table III, show that the $\mathrm{LD}_{50}$ of mice challenged 1 week after one injection of 1.0 $\mu \mathrm{g}$ of either treated or untreated endotoxin increased about threefold over that of the controls. The $L D_{50}$ values of the immunized animals and the controls were computed by probit analysis and the difference was found to be statistically highly significant $(p<0.01)$.

Influence of reaction time and stoichiometry of reagents. A few experiments with varying pro-
TABLE III

Increased resistance of mice against lethal toxicity of endotoxin 7 days after immunization with one injection of 1.0 $\mu \mathrm{g}$ of regular and $\mathrm{LiAlH}_{4}$-treated endotoxin

\begin{tabular}{cccc}
\hline \hline & & \multicolumn{2}{c}{ Fraction dead after 72 hours } \\
\cline { 3 - 4 } $\begin{array}{c}\text { Challenge } \\
\text { dose }\end{array}$ & $\begin{array}{c}\text { Nonimmunized } \\
\text { controls }\end{array}$ & $\begin{array}{c}\text { Immunized, } \\
\text { regular endo. }\end{array}$ & $\begin{array}{c}\text { Immunized, } \\
\text { LiAlH4-treated endo.* }\end{array}$ \\
\hline$m g$ & & & \\
0.063 & $4 / 10$ & $1 / 10$ & $0 / 10$ \\
0.125 & $4 / 10$ & $3 / 10$ & $1 / 10$ \\
0.25 & $10 / 10$ & $1 / 10$ & $2 / 10$ \\
0.50 & $10 / 10$ & $8 / 10$ & $9 / 10$ \\
1.00 & $10 / 10$ & $10 / 10$ & $10 / 10$ \\
LD & 0.10 & 0.29 & 0.31 \\
\hline
\end{tabular}

* Half the mice were immunized with preparation RE I, the other half with RE II. Statistical considerations showed that pooling of the

data was permissible and desirable.
t Computed by probit analysis (23).

portions of reagent were carried out in order to obtain some information on the stoichiometry and time course of the reaction. Samples of $10 \mathrm{mg}$ endotoxin were treated with $0.1,1.0$ and $100 \mathrm{mg}$ of $\mathrm{LiAlH}_{4}$ for 1 hour in the usual way. The reaction was stopped by the addition of water, the aqueous solutions neutralized, and adjusted to a volume of $5 \mathrm{ml}$. The insoluble hydroxides were removed by centrifugation and the supernatants

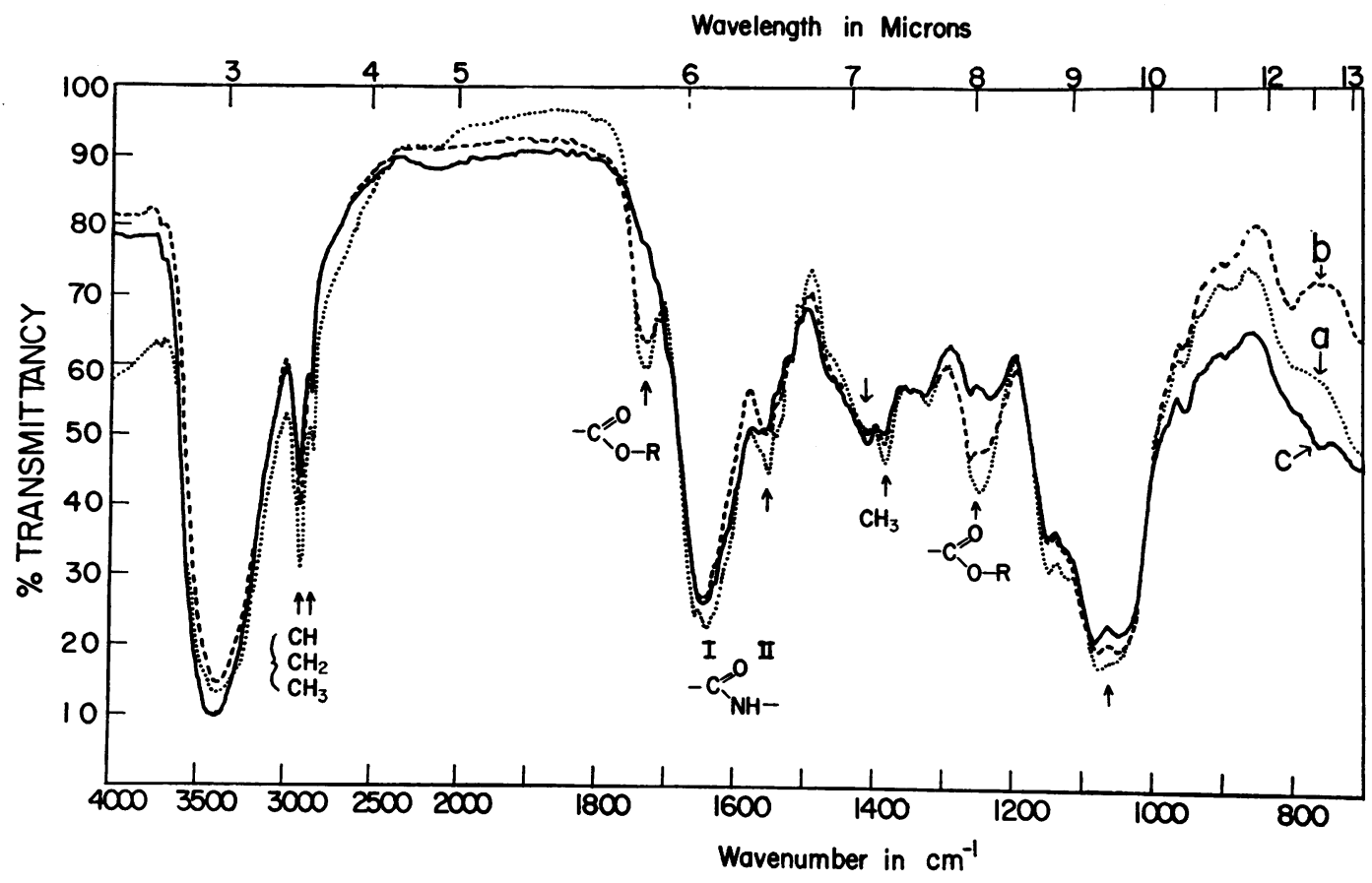

Fig. 4. Changes IN INFRAREd SPECTRUM OF ENDOTOXIN AFTER tREATMENT With VARIOUS PROPORTIONS of $\mathrm{LIAlH}_{4}$. a) Untreated endotoxin. b) Treated with $0.1 \mathrm{mg} \mathrm{LiAlH}_{4}$ per $10 \mathrm{mg}$ endotoxin. c) Treated with $1.0 \mathrm{mg}$. Samples were pressed into $5 \mathrm{mg} \mathrm{KBr}$ pellets containing $36 \mu \mathrm{g}$ endotoxin. 
TABLE IV

Reduction of pyrogenicity and recovery of reaction product after treatment of endotoxin with various proportions of $\mathrm{LiAlH}_{4}$ and for different reaction periods

\begin{tabular}{|c|c|c|c|c|c|c|c|c|}
\hline Preparation & $\begin{array}{l}\text { Endo- } \\
\text { toxin }\end{array}$ & $\mathrm{LiAlH}_{4}$ & $\begin{array}{c}\% \text { } \mathrm{LiAlH}_{4} \\
\text { of endo. } \\
\text { wt }\end{array}$ & $\begin{array}{l}\text { Endo. } \\
\text { adsorbed } \\
\text { to } \mathrm{Al}(\mathrm{OH})_{3}\end{array}$ & $\frac{\mathrm{mg} \text { adsorbed }}{\mathrm{mg} \mathrm{Al}(\mathrm{OH})_{3}}$ & $\begin{array}{c}\text { Reaction } \\
\text { period }\end{array}$ & $\begin{array}{l}\text { Pyrogenicity } \\
\text { in \% of un- } \\
\text { treated endo. }\end{array}$ & $\begin{array}{c}\text { IR } \\
\text { spectrum }\end{array}$ \\
\hline & $m g$ & $m g$ & & $\%$ & & hrs & & Figure \\
\hline RE III & 10 & 0.1 & 1 & 16 & & 1 & $\sim 100$ & $4 b$ \\
\hline RE IV & 10 & 1.0 & 10 & 40 & 2.0 & 1 & $\sim 1$ & $4 c$ \\
\hline RE I & 300 & 150 & 50 & 87 & 0.9 & 6 & $<0.001$ & $2 a$ \\
\hline RE II & 50 & 100 & 200 & 93 & 0.23 & 5.5 & $<0.001$ & $*$ \\
\hline RE V & 10 & 100 & 1,000 & 96 & 0.05 & 1 & $\dagger$ & $\dagger$ \\
\hline
\end{tabular}

* Similar to Figure 2a (not shown).

$\dagger$ Not tested because of lack of material.

(RE III, IV, V) assayed for carbohydrate. Spectroscopic and pyrogenicity determinations were carried out with the residues obtained after lyophilization of the deionized aqueous solutions RE III and Re IV. The results of this and the previous two experiments, summarized in Table IV, show that both efficiency of inactivation and adsorption losses increase with increasing amounts of reducing agent per milligram of endotoxin. If the reagent exceeds about 50 per cent of the weight of the endotoxin, the adsorption losses approach 90 per cent. Near saturation-i.e., with an excess of endotoxin - the aluminum hydroxide gel can bind about twice its weight of endotoxin (RE IV).

The effect of increasing proportions of reducing agent on the chemical structure of endotoxin is best visualized by comparison of the infrared spectra of the preparations listed in Table IV. The spectral changes reflecting various degrees of reduction are illustrated by the three superimposed recordings in Figure 4. It can be seen that treatment with even the smallest proportion of $\mathrm{LiAlH}_{4}$
(0.1 $\mathrm{mg}$ per $10 \mathrm{mg}$ endotoxin), which failed to produce a measurable decrease in pyrogenicity, caused a marked reduction, corresponding to about 25 per cent of the absorptions associated with ester groups (curve b). Further increase of the reducing agent to $1 \mathrm{mg} \mathrm{LiAlH}_{4}$ per $10 \mathrm{mg}$ endotoxin gave a product of about 100 -fold reduced pyrogenicity, which shows only a trace of ester carbonyl at $1,735 \mathrm{~cm}^{-1}$ (curve c). Chemical determination (20) of the ester content of the untreated endotoxin gave a value of $0.27 \mu$ mole ester linkages per $\mathrm{mg}$, corresponding to an esterbound fatty acid content of 5 to 10 per cent. The finding that, after reductive cleavage, only about 2 per cent ether-soluble lipid was recovered in the form of aliphatic alcohols suggests that the major portion was adsorbed to the aluminum hydroxide gel.

The analysis of the stoichiometry and kinetics of the reaction is complicated by the presence in endotoxin of a large proportion of labile hydrogen which reacts rapidly with hydride to form complexes that are later decomposed with water.

TABLE V

Effect of treatment with $\mathrm{LiOH}$ on toxicity and $\mathrm{CO}$ stretching absorption of endotoxin

\begin{tabular}{|c|c|c|c|c|c|c|c|}
\hline \multirow[b]{2}{*}{ Preparation } & \multirow[b]{2}{*}{ Endo. } & \multicolumn{2}{|c|}{$\mathrm{LiOH}$ concentration } & \multirow[b]{2}{*}{$\begin{array}{l}\text { Reaction } \\
\text { period }\end{array}$} & \multirow[b]{2}{*}{$\mathrm{LD}_{50} *$} & \multirow[b]{2}{*}{ Toxicity } & \multirow[b]{2}{*}{$\begin{array}{l}\text { Absorption } \\
\text { intensity } \\
\text { at } 1,250 \mathrm{~cm}^{-1}\end{array}$} \\
\hline & & & $\begin{array}{l}\text { LiAlH4 }_{4} \\
\text { equiv. }\end{array}$ & & & & \\
\hline & $m g$ & moles $/ L$ & $m g / 10 m l$ & hrs & $m g$ & $\%$ & $\%$ \\
\hline & 50 & 0 & 0 & 0 & 0.098 & 100 & 100 \\
\hline HE I & 50 & 0.005 & 2 & 1 & 0.176 & 56 & 85 \\
\hline HE II & 50 & 0.01 & 4 & 1 & 0.211 & 46 & 64 \\
\hline HE III & 50 & 0.025 & 10 & 1 & 0.324 & 30 & 48 \\
\hline HE IV & 50 & 0.1 & 40 & 1 & & & 48 \\
\hline HE V & 50 & 0.25 & 100 & 1 & 0.522 & 19 & 48 \\
\hline HE VI & 50 & 0.25 & 100 & 48 & & & 48 \\
\hline
\end{tabular}

* Estimated by the method of Reed and Muench (34). 
This side reaction consumes a relatively large proportion of reagent. Replacement of labile hydrogen, most of which is associated with the carbohydrate portion, is calculated to require an amount of $\mathrm{LiAlH}_{4}$ corresponding to 10 to 20 per cent of the endotoxin weight. Reductive cleavage of all ester bonds, on the other hand, would consume only $0.5 \mathrm{mg} \mathrm{LiAlH}_{4}$ per $100 \mathrm{mg}$ of endotoxin.

Subsequent experiments indicated that reductive cleavage of ester bonds alone fails to explain the observed loss of pyrogenicity. When the formation of insoluble $\mathrm{Al}(\mathrm{OH})_{3}$ was prevented with sodium potassium tartrate (33), or when the reduction was carried out in aqueous solution with $\mathrm{LiBH}_{4}$ or $\mathrm{NaBH}_{4}$, only moderate reduction of toxicity occurred, despite the disappearance of the ester carbonyl band at $1,735 \mathrm{~cm}^{-1}$ in the infrared spectra of the reaction products. Apparently, the toxic products remaining after reduction with $\mathrm{LiAlH}_{4}$ are preferentially adsorbed to the aluminum hydroxide gel. This was demonstrated by dividing the reduced reaction mixture into two portions, one of which was decomposed with dilute $\mathrm{HCl}$ as usual, the other with a saturated solution of sodium potassium tartrate. The fraction of the reaction product of the first portion which did not adsorb to $\mathrm{Al}(\mathrm{OH})_{3}$ was free of pyrogenicity, whereas the product isolated from the tartrate solution had retained its toxic properties.

Alkaline hydrolysis. Endotoxin was treated with various concentrations of lithium hydroxide, in order to distinguish the chemical and biological effects caused by the reducing action of $\mathrm{LiAlH}_{4}$ from those that are attributable to the hydrolytic action of its water-soluble alkaline decomposition product.

The $\mathrm{LiOH}$ concentrations and reaction periods are listed in Table $\mathrm{V}$, together with the results of infrared spectrophotometry and mouse toxicity tests. The spectra of the samples treated with increasing concentrations of $\mathrm{LiOH}$ are reproduced in Figure 5. The results show that alkali causes both a reduction of toxicity and hydrolysis of ester bonds. The extent of hydrolysis after 1 hour, as measured by the intensity decrease of the ester bands near 1,735 and $1.250 \mathrm{~cm}^{-1}$, was dependent upon the alkali concentration up to about $0.02 \mathrm{M}$ and reached a value of about 50 per

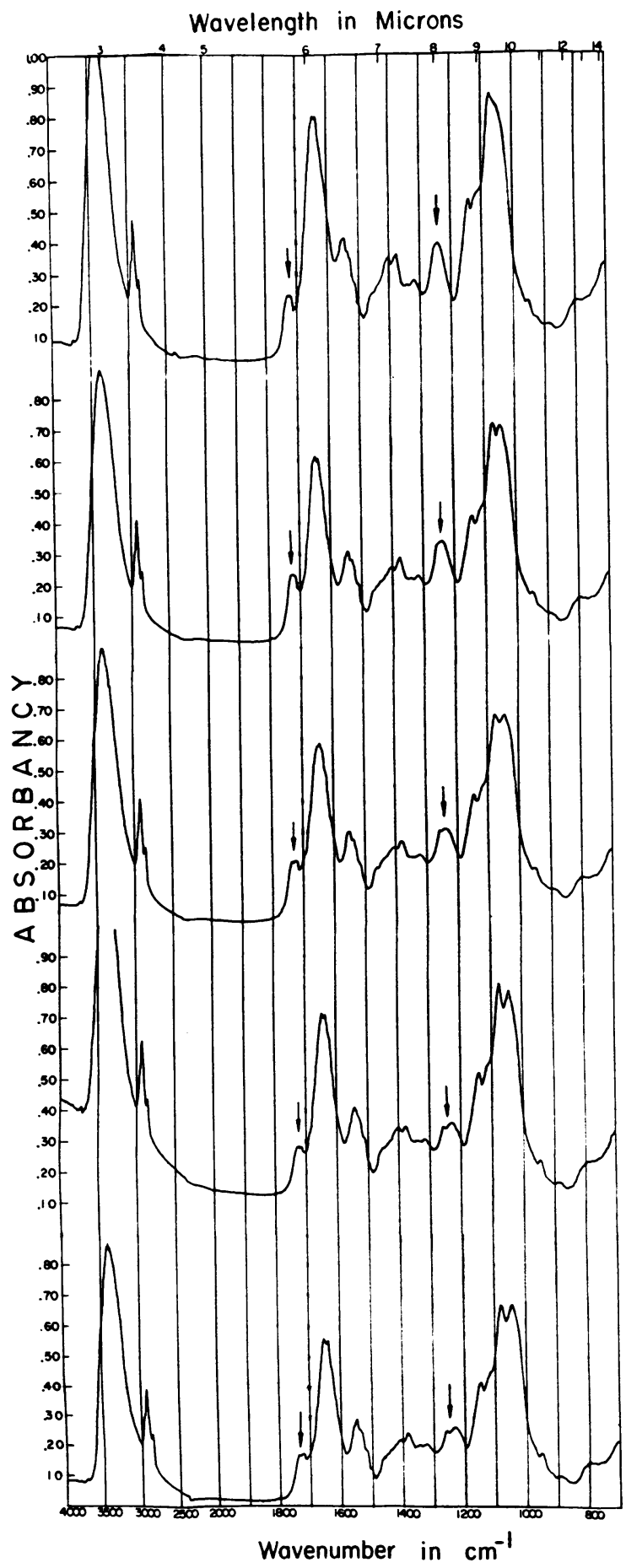

Fig. 5. Changes In INFrared SPECTRUM OF ENDOTOXIN AFTER TREATMENT WITH INCREASING CONCENTRATIONS OF LIOH, CORRESPONDING TO (FROM TOP) $0,0.005$, $0.010,0.025,0.25 \mathrm{M}$. Arrows indicate ester absorptions. ( $\mathrm{KBr}$ pellets, $5 \mathrm{mg}$, containing $36 \mu \mathrm{g}$ endotoxin.) 
cent; an increase of the $\mathrm{LiOH}$ concentration to a final value of $0.25 \mathrm{M}$ failed to cause further reduction of the ester absorption bands even after 48 hours' reaction time, as is evident from the infrared spectrum in Figure 5, curve 5. The reduction of toxicity as a function of the alkali concentration is shown in Figure 6. The $\mathrm{LD}_{50}$ is proportional to the log of the $\mathrm{LiOH}$ concentration, a tenfold increase of the latter producing an $\mathrm{LD}_{50}$ increase of $0.21 \mathrm{mg}$. Spectroscopic analysis, on the other hand, shows no difference between the spectra of the samples treated with $0.025 \mathrm{M} \mathrm{LiOH}$ for 1 hour and with a tenfold higher alkali concentration for 24 hours. Because of the lack of a strict quantitative correlation, it is doubtful that the moderate reduction of toxicity caused by alkali is directly related to the hydrolysis of ester bonds. This conclusion is in agreement with previous observations which indicated that alkaline hydrolysis under comparable conditions resulted in partial removal of lipid without significant reduction of pyrogenicity and toxicity (24).

Treatment of endotoxin with either $\mathrm{LiOH}$ or $\mathrm{LiAlH}_{4}$ is accompanied in each case by an increasing separation of the broad absorption near 1,060 $\mathrm{cm}^{-1}$ into two distinct bands. However, in addition to these changes, alkali treatment, in contrast to reduction with $\mathrm{LiAlH}_{4}$, also causes an increased separation of the amide I and II bands. This effect seems to be associated with the most alkali-sensitive portion of endotoxin, since it is caused by the lowest $\mathrm{LiOH}$ concentration tested

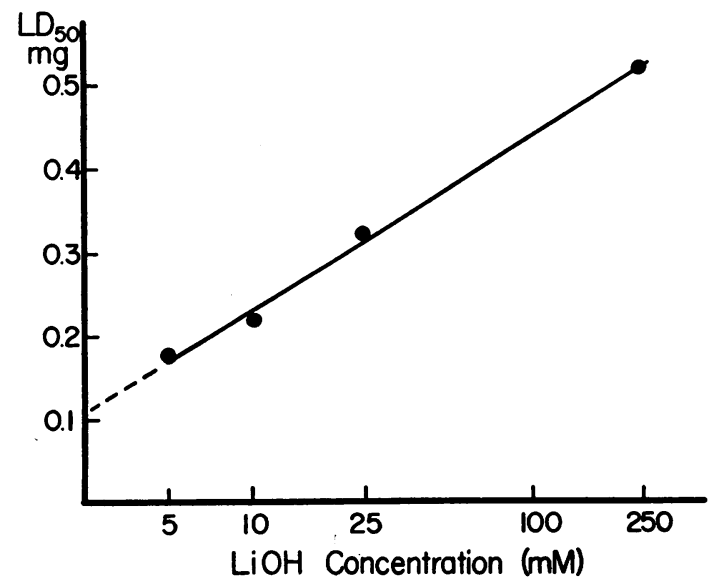

FIg. 6. LINEAR INCREASE OF LD $_{30}$ FOR MICE WITH LOG OF LIOH CONCENTRATION AFTER TREATMENT OF ENDOTOXIN FOR 1 HOUR AT $22^{\circ} \mathrm{C}$.
$(0.005 \mathrm{M})$ and is not noticeably enhanced at higher concentrations. This suggests that the observed spectral change results from a modification of the protein or peptide moiety which is known to adsorb in this region. This explanation is supported by the observed reduction of immunizing power of alkali-treated endotoxin preparations and the well known sensitivity of proteins to conditions of high $\mathrm{pH}$. These data emphasize again the contrast between the lability of the immunogenic properties of endotoxin and the resistance of its toxicity toward alkali.

Antigenic analysis. In order to obtain further information on the immunizing properties and antigenic composition of various endotoxin preparations, rats were immunized and their sera analyzed for precipitating antibodies by the agar diffusion technique. Antisera produced with live and heat-killed $E$. coli cultures, as well as with Boivin antigen before and after treatment with $\mathrm{LiAlH}_{4}$ and $\mathrm{NaOH}$ were each tested against four different antigens. The sera were collected at intervals over a 30 -day period in order to follow the time course of the immune response. A complete synopsis of this experiment, showing the precipitin patterns obtained with the various antisera placed in the center and the antigens in the outer wells, is reproduced in Figure 7. Although all preparations were antigenic, the antibody response which they elicited varied considerably with regard to time, quality and intensity. The appearance of more than one band indicates chemical heterogeneity of the antigen preparations; by this test, autoclaved culture filtrates and untreated Boivin antigen contained at least two components, while the $\mathrm{LiAlH}_{4}$ - and alkali-degraded products contained three. So-called reactions of identity, characterized by the complete joining of the precipitin bands, occurred when different antigen preparations were tested against a given antiserum as well as in the reversed test. Analysis of the identity reactions indicated that all antigen preparations had at least one serologically reactive configuration in common.

The most rapid formation of completely crossreacting antibodies was induced by the nontoxic, $\mathrm{LiAlH}_{4}$-treated preparation (RE I). Sera obtained 4 days after the second injection of this antigen reacted with two precipitin bands against all antigens; after 8 days the inner bands began 


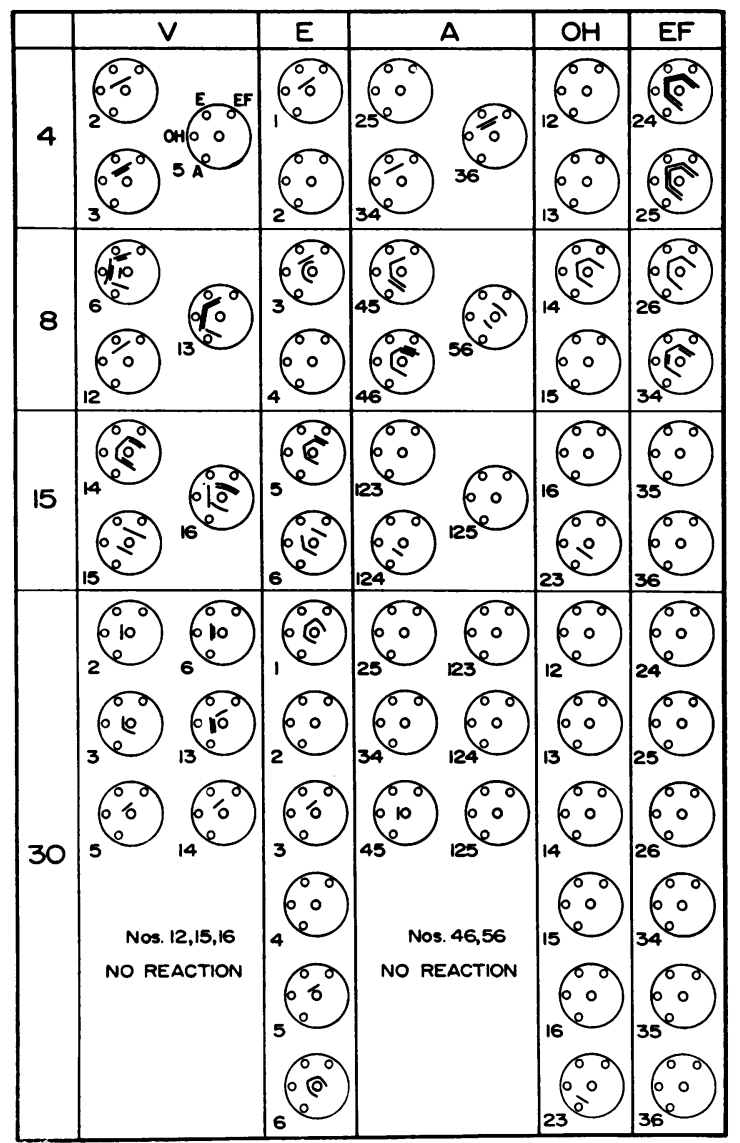

Fig. 7. Development of precipitating antibodies in SERA OF RATS IMMUNIZED WITH VARIOUS ENDOTOXIN PREPARATIONS AS DEMONSTRATED BY THE OUCHTERLONY AGAR DIFFUSION TECHNIQUE. Antisera, prepared by the antigens shown at the top of each column, were placed in center wells and tested against the four antigens in the outer wells as indicated by the code. The sera were collected from individual rats $4,8,15$ and 30 days after the second immunizing injection as indicated in the vertical column at left. The identification number of each immunized rat is placed to the left of each diffusion plate. Antigens: $\mathrm{V}=$ viable $E$. coli (18-hour broth culture containing $10^{\circ}$ organisms per $\mathrm{ml}$ ) $; \mathrm{E}=$ untreated endotoxin; $\mathrm{A}=$ autoclaved $E$. coli (18-hour broth culture autoclaved for 2.5 hours at $120^{\circ} \mathrm{C}$ and $15 \mathrm{lbs}$ pressure); $\mathrm{OH}=$ $\mathrm{NaOH}$-treated endotoxin; $\mathrm{EF}=\mathrm{LiAlH}_{4}$-treated endotoxin RE I.

to disappear, and by 15 days no precipitating antibodies were detectable. A different pattern was shown by the antibody response resulting from immunization with either live E. coli or untreated endotoxin. In these cases, the antibodies appearing after 4 days gave precipitin reactions with unheated culture filtrates of $E$. coli and native
Boivin antigen only. After 8 days, the antisera reacted with the alkali-treated endotoxin and with the soluble antigens of the autoclaved $E$. coli cultures and, finally, after 15 days with the $\mathrm{LiAlH}_{4}$-treated antigen. This suggests that the native antigens are slowly degraded in vivo to products of increasing immunochemical similarity with the chemically modified test antigens. It is interesting that the chemically modified preparations could still induce the formation of antibodies capable of reaction with the original antigens, whereas the early antibodies elicited by the native antigens failed to precipitate with the modified antigen. This nonreciprocal cross reaction may be explained by the concept of competition of antigens as extended to different antigenic regions within the same molecule $(35)$ : the determinant region (epitype ${ }^{1}$ ) $a$ which was immunogenically dominant in the original antigen must have been lost during treatment with $\mathrm{LiAlH}_{4}$, thus allowing in the modified antigen the immunogenic expression of the previously repressed epitype $b$.

Other modifications of the immunogenic properties caused by detoxification are reflected in the greater intensity and shorter duration of the antibody response. The disappearance of antibodies within 15 days after the second immunizing dose suggests that the detoxified antigen is more rapidly metabolized than is the native endotoxin which stimulated the formation of antibodies for more than 30 days.

Alkali treatment, in contrast to reduction with $\mathrm{LiAlH}_{4}$, greatly decreased the immunizing potency of the Boivin antigen, as indicated by the large proportion of rats which failed to respond and by the transient appearance after 8 days of only single precipitin bands against all antigens. Serological activity, on the other hand, was retained, since the $\mathrm{NaOH}$-degraded product reacted strongly with the development of up to three bands against immune sera prepared with the other antigens. The alkali-treated haptene also showed a strong affinity for the surface of human erythrocytes, as demonstrated first by Neter and associates (24) and confirmed by the results of the hemagglutination tests in these experiments. In

\footnotetext{
1 General adoption of the new terminology proposed by Jerne (36) is recommended, because it avoids present ambiguities and permits a more concise formulation of immunological concepts.
} 
TABLE VI

Protection of rats against renal infection with $\mathrm{E}$. coli after immunization with $\mathrm{LiAlH}_{4}$-treated endotoxin

\begin{tabular}{|c|c|c|c|c|c|c|}
\hline & \multirow{2}{*}{$\underset{\mathbf{n}}{\text { Rats, }}$} & \multirow{2}{*}{$\begin{array}{l}\text { Deaths } \\
\text { after } \\
\text { infection }\end{array}$} & \multicolumn{2}{|c|}{ Average weight at } & \multirow{2}{*}{$\begin{array}{c}\text { Geometric mean* of } \\
\text { number } N \text { of viable } \\
E \text {. coli per } g \\
\text { kidney at sacrifice }\end{array}$} & \multirow[b]{2}{*}{$\log \mathrm{SD}$} \\
\hline & & & Infection & Sacrifice & & \\
\hline & no. & no. & $g$ & $g$ & & \\
\hline Immunized & 20 & 0 & 366 & 371 & $1.0 \times 10^{5}$ & 1.76 \\
\hline Nonimmunized & 20 & 3 & 357 & 334 & $25 \times 10^{5}$ & 0.71 \\
\hline
\end{tabular}

*Antilog $[(\Sigma \log N) / \mathrm{n}]$.

contrast, when red cells from the same source were exposed to the $\mathrm{LiAlH}_{4}$-treated antigen under identical conditions, they could not be agglutinated by rabbit antisera which had a titer of $1: 1000$ with respect to erythrocytes sensitized with alkali-degraded endotoxin. This finding may be explained by the concept that lipid-lipid interactions play an essential role in the attachment to red cell surfaces (37).

Immunization of rats against pyelonephritis. The results reported in the previous sections show that immunization of animals with the nontoxic antigen provided protection against the toxic effects of $E$. coli. It was interesting to test whether this protective effect was also directed against the infection per se. The usual methods of determining the resistance against lethal challenge doses of live $E$. coli, however, fail to provide a measure of antibacterial immunity, since, under these conditions, death results primarily from the action of endotoxin. Experimental pyelonephritis, on the other hand, provides a more specific measure of infection by $E$. coli (38).
The results, summarized in Tables VI-VIII, show that immunization of rats with the nontoxic antigen (RE I) provided effective protection against experimental pyelonephritis comparable with that observed after immunization with the untreated parent endotoxin (39). The group of immunized animals gained weight and none of the rats died during the 26 days of the experiment, whereas the control group lost weight and three deaths occurred within 48 hours after the challenge infection. The geometric mean of the average bacterial count in the kidneys was reduced 25fold in the immunized group (Table VI). A more detailed analysis of these findings is summarized in Table VII, in which the individual kidneys of the control and immunized group are ranked according to their viable bacterial count per gram of tissue. The resulting frequency distribution shows a striking difference between the two groups. Thus, 45 per cent of the kidneys of the immunized rats contained less than $10^{5}$ viable bacteria per $\mathrm{g}$ of tissue compared with only 3 per cent in the nonimmunized controls. It is inter-

TABLE VII

Protective effect of immunization with detoxified endotoxin in E. coli-infected rats

\begin{tabular}{|c|c|c|c|c|c|c|c|}
\hline \multirow[b]{2}{*}{$\begin{array}{c}\text { Class } \\
\text { interval }\end{array}$} & \multirow[b]{2}{*}{$\begin{array}{c}\text { Bacteria/ } \\
\text { g kidney } \\
\text { tissue* }\end{array}$} & \multicolumn{3}{|c|}{ Nonimmunized controls } & \multicolumn{3}{|c|}{ Immunized rats } \\
\hline & & Kidneys & Accumulative & $\begin{array}{c}\text { Av. } \\
\text { grade } \\
\text { pyelo- } \\
\text { nephritis }\end{array}$ & Kidneys & Accumulative & $\begin{array}{c}\text { Av. } \\
\text { grade } \\
\text { pyelo- } \\
\text { nephritis }\end{array}$ \\
\hline & no. & no. & $\%$ & & no. & $\%$ & \\
\hline $\mathbf{X}$ & $3.2 \times 10^{7}$ & 1 & 100 & 1.0 & 0 & & \\
\hline IX & $1.0 \times 10^{7}$ & 4 & 97 & 1.3 & 5 & 100 & 1.4 \\
\hline VIII & $3.2 \times 10^{6}$ & 10 & 84 & 2.2 & 2 & 87 & 2.0 \\
\hline VII & $1.0 \times 10^{6}$ & 9 & 53 & 2.8 & 3 & 82 & 1.7 \\
\hline VI & $3.2 \times 10^{5}$ & 3 & 25 & 1.3 & 8 & 74 & 1.1 \\
\hline V & $1.0 \times 10^{5}$ & 4 & 16 & 2.2 & 3 & 53 & 1.0 \\
\hline IV & $10^{4}$ & 1 & 3 & 2.0 & 7 & 45 & 1.1 \\
\hline III & $10^{3}$ & 0 & 0 & & 6 & 26 & 0 \\
\hline II & $10^{2}$ & 0 & 0 & & 1 & 11 & 0 \\
\hline I & 0 & 0 & 0 & & 3 & 8 & 0 \\
\hline
\end{tabular}

* Numbers in this column represent the lower limits of each class interval; e.g., class IV is defined by bacterial counts falling within $10^{4}$ and $10^{5}$ bacteria per $g$ tissue. 
esting to note that, in addition to the reduction of the mean bacterial count, immunization also causes a larger spread of the distribution, which is reflected in a more than twofold increase of the standard deviation, calculated on the basis of a $\log$ normal distribution with respect to the bacterial counts (Table VI). A similar effect has been observed in chemotherapeutic studies (40).

A comparison of the bacterial counts with the extent of pyelonephritis (Table VII) shows no strict parallelism between these two manifestations of infection. Whereas kidneys containing fewer than $10^{4}$ bacilli per $g$ were free of pyelonephritis, the kilneys with the largest lesions did not show the highest bacterial counts. This observation is consistent with earlier findings which showed that, during the course of infection, the kidneys tend to become sterile, while the tissue destruction often continues in the absence of viable bacilli (38).

Table VII further shows that immunization greatly reduced the severity of pyelonephritis even in those kidneys which contained the same number of viable bacilli as the nonimmunized controls. This is revealed more clearly by ranking the infected kidneys according to the extent of the lesions. The resulting frequency distribution (Table VIII) shows that over 90 per cent of the controls had lesions of all severity grades, with a peak frequency of grade 2 . In contrast, 50 per cent of the immunized group was free of pyelonephritis, and the remaining kidneys showed considerably less involvement than the controls.

The persistence of pyelonephritis in the absence of viable $E$. coli suggests that the inflammatory reaction may be largely due to the endotoxin formed in the kidney during the infection. The reduction of pyelonephritis, which was observed

TABLE VIII

Reduction of E. coli-induced pyelonephritis in rats immunized with detoxified endotoxin

\begin{tabular}{cccccc}
\hline & \multicolumn{2}{c}{$\begin{array}{c}\text { Nonimmunized } \\
\text { controls }\end{array}$} & & \multicolumn{1}{c}{ Immunized rats } \\
$\begin{array}{c}\text { Extent } \\
\text { of } \\
\text { lesions }\end{array}$ & Kidneys & $\begin{array}{c}\text { Accumu- } \\
\text { lative }\end{array}$ & Kidneys & $\begin{array}{c}\text { Accumu- } \\
\text { lative }\end{array}$ \\
\cline { 5 - 6 } grade & $n o$. & $\%$ & & $n o$. & $\%$ \\
4 & 4 & 100 & 1 & 100 \\
3 & 7 & 88 & 5 & 97 \\
2 & 15 & 68 & 7 & 85 \\
1 & 5 & 24 & 7 & 68 \\
0 & 3 & 9 & 20 & 50 \\
\hline
\end{tabular}

when kidneys of immunized rats were compared with controls containing a similar number of viable bacteria (Table VII), is consistent with this interpretation, since immunization with detoxified endotoxin has been shown to increase the resistance against the toxic effects of the original endotoxin. The resulting immunity, however, was also directed against the bacterial cells, as is obvious from the smaller number of viable bacteria present in the kidneys of the immunized rats. Since endotoxin is a major constituent of the bacterial surface and is known to produce antibodies capable of bacterial agglutination, the more rapid elimination of viable bacteria in immune animals may be readily explained by classical immunological mechanisms, such as enhanced phagocytosis. The lack of congruence shown by the frequency distributions of the different criteria used for the quantitative measurement of protection suggests that antibacterial immunity is a rather complex phenomenon which develops by a number of separate and at least partially independent mechanisms.

\section{DISCUSSION}

The present study describes the preparation of a nonpyrogenic Boivin antigen of high immunogenic potency. All of the toxic phenomena tested -i.e., pyrogenicity for rabbits, lethality for mice, and induction of neutropenia in rabbits and intradermal inflammation in man-were greatly reduced or abolished by a chemical procedure which did not seem to cause extensive fragmentation of the molecule. The conclusion appears justified, therefore, that a single molecular configuration is responsible for all of these toxic manifestations. It further follows that integrity of the molecular structures necessary for toxicity is not an essential requirement for immunogenic activity. Moreover. the successful separation of these two biological activities made it possible, for the first time, to study the immunizing and protective activities of endotoxin without interference from the effects of toxicity.

Chemical basis of toxicity. A definite identification of the chemical structures responsible for toxicity has not been achieved, mainly because the lack of sufficient material prevented an extensive chemical characterization of the detoxified product. While it was consistently found that only 
preparations that were free of all detectable ester carbonyl were nonpyrogenic, the crude esterfree reaction product was still highly toxic. In order to obtain a nonpyrogenic material, subsequent partitioning on aluminum hydroxide gel was necessary. This step apparently resulted in the adsorptive removal of toxic fractions. The elimination of ester-bound fatty acids by $\mathrm{LiAlH}_{4}$ may therefore not be directly related to the process of detoxification. ${ }^{2}$ It should also be pointed out that a portion of the fatty acids in endotoxin is bound through amide linkages (42) which are not split by $\mathrm{LiAlH}_{4}$. With the exception of carboxyesters, there is no evidence for the presence in endotoxin of groups that are known to be readily reduced with $\mathrm{LiAlH}_{4}$. The infrared spectra of the reduction products indicate that most of the peptide linkages remained intact; acetal and glycosidic bonds in carbohydrates have generally been found resistant against this reducing agent (43). This is also supported by the observed preservation of immunogenic potency and serological specificity. It has not been determined, however, whether $\mathrm{LiAlH}_{4}$ is capable of cleaving phosphodiester linkages.

Degradation studies with alkali failed to show a direct quantitative relationship between rate and extent of hydrolysis of ester bonds and reduction of toxicity. At the highest concentration tested $(0.25 \mathrm{~N}) \mathrm{LiOH}$ caused only a 50 per cent ester hydrolysis and a fivefold reduction of lethality for mice. Immunogenicity, on the other hand, was almost completely destroyed, whereas serological activity, in agreement with previous observations $(3,24)$, was preserved. These results suggest that under mild conditions, alkali degrades endotoxin primarily by attacking bonds other than ester linkages, most likely by hydrolysis of certain peptide bonds.

The problem of the chemical basis of toxicity has been a matter of debate. From experiments with artificial complexes, Westphal concluded that

\footnotetext{
2 Johnson (41) described the preparation from Shigella sonnei of a protein-lipocarbohydrate antigen which was devoid of lethal toxicity for mice and protected mice against lethal challenge doses of the parent organism. Although the chemical relationship of this material to the toxic $\mathrm{O}$-antigens is not known, this finding suggests that the normally toxic $\mathrm{O}$-antigen preparations might be partitioned into toxic and nontoxic fractions even without prior chemical modification.
}

the lipid A portion was responsible for toxicity (7), whereas Ribi and co-workers and Tauber, impressed by the apparent lack of a correlation between toxicity and lipid content of different preparations $(2,20)$, attributed toxicity to the polysaccharide moiety (2). The present results, while not providing decisive evidence for either view, tend to favor the idea that toxicity is the result of certain physicochemical properties characteristic of the entire molecule, rather than the autonomous property of one of its components.

Antigenic analysis. Further information on the biological properties of endotoxin was obtained from immunization studies. The rat was chosen as the most suitable experimental animal, because it responded more uniformly with the formation of precipitating antibodies against small doses of endotoxin than does the rabbit. It should be emphasized that the wider use of the rabbit for immunological studies and its superior response to certain other antigens does not eo ipso make it a more acceptable test system for immunization experiments with endotoxin.

Antigenic analysis by the Ouchterlony technique revealed the presence of two major components in all preparations tested. It is interesting that, even with an extensively purified Boivin antigen of low nitrogen content, Landy, Johnson, Webster and Sagin found three reactive components against rabbit antiserum in Oudin's agar gel diffusion test (3). So far, no endotoxin preparations have been shown to be immunochemically homogenous by such tests.

The immunochemical relationship between the various antigens used for immunization and the effects of chemical treatment on the antigenic structure were most strikingly reflected in the changing cross reactivity of the antibodies during the course of immunization. The precipitating antibodies appearing early in the sera of rats immunized with live or autoclaved $E$. coli. cultures or with native endotoxin reacted only with the latter antigen but not with the alkali- or $\mathrm{LiAlH}_{4}$-treated preparations. This illustrates the close similarity of the Boivin antigen with the antigenic structure of the bacterial surface. The antibodies elicited by the detoxified preparation, on the other hand, immediately gave strong cross reactions with all other antigens, as is evident from the appearance of two concentric and completely joined band systems. 
This is contrary to the loss of reactivity toward the parent antigen usually observed with antibodies prepared against chemically modified antigens (44). Of considerable interest was the observation that the reaction of the native Boivin antigen with its homologous antiserum consistently produced only one precipitin band during the observed 30-day immunization period, despite the presence of a second antigenic component capable of precipitation with the sera from rats immunized with the detoxified antigen. These results indicate that the specificity of the antibodies elicited by the native Boivin antigen is mainly directed against those molecular structures that are modified during the process of detoxification.

In contrast to the extensive elucidation of the structural features of the polysaccharide moiety responsible for the O-antigenic serological specificity (45), little is known about the factors determining the immunogenicity of endotoxin. The well documented loss of immunizing power after exposure of endotoxin to phenol suggested that the dissociable protein is essential for immunogenicity (7). This explanation is contradicted by the finding that the immunogenic potency of Boivin antigen increased during removal of associated protein by methods other than phenol dissociation. Subsequent treatment of the "protein-free" preparation with phenol, however, destroyed the immunizing properties (1). The poor immunogenicity of phenol-treated lipopolysaccharide preparations was confirmed during the present investigations. Thus, antisera of rats, immunized with Westphal's highly purified lipopolysaccharide, failed to give any visible reaction with homologous or heterologous antigen when tested by the Ouchterlony technique together with known reference samples and under the same conditions as described in Materials and Methods. Immunization of rabbits with Westphal's preparation, on the other hand, produced a significant rise in hemagglutinin titers. Nevertheless, the potency of the native Boivin antigen was still considerably greater than that of the phenol-extracted lipopolysaccharide when the two preparations were compared on an equal weight basis in the rabbit.

Protective immunization. It is well established that immunization of animals with endotoxin increases their resistance against the toxic effects of subsequent challenge doses of endotoxin as well as against infection with the corresponding or related bacteria. The mechanisms responsible for these effects are often called nonspecific and, as implied by the term tolerance, are thought to reflect a nonimmunological change in host susceptibility brought about by the toxic properties of the molecule. The present findings do not support this notion, since most of the protective effects of endotoxin-e.g., pyrogen tolerance, and increased resistance to lethal toxicity as well as to infectious pyelonephritis-have now been produced with a chemically modified antigen of greatly reduced toxicity. Rather, these results seem to favor an immunological interpretation of the observed tolerance. Other observations that may be cited in support of this view are the passive transfer of tolerance with serum from tolerant animals (46), the tolerant fever responses observed after injection of mixtures of endotoxin with high titer homologous antiserum (47), the rapid rise of antibody titers in response to minute doses of endotoxin (3), and the linear relationship between the O-agglutinin titers of rabbit sera and their potency $\left(\mathrm{ED}_{50}\right)$ to protect mice against lethal challenge doses of the homologous organism (Salmonella typhosa) $(3,48)$.

The preparation of effective, nontoxic vaccines against gram-negative bacteria has been an unsolved problem of great practical importance. An interesting new approach was the recent preparation by Lüderitz, Westphal, Staub and Le Minor of an artificial antigen with colitose as the determinant group (49). Goats immunized with this preparation elicited antibodies capable of agglutinating certain strains of $E$. coli. It would be interesting to know whether these antigens are also capable of providing immunological protection against the toxic effects of endotoxin and against infection. The approach reported here appears to be of practical value, since it has been shown that chemical modification of a therapeutically interesting antigen may serve to improve its desirable properties, such as immunogenic potency, range of cross reactivity and freedom from toxicity. Efforts are now being made to determine the optimal conditions of detoxification, to standardize the reproducibility of the procedures and to increase the yields of the detoxified antigen for further chemical studies and for vaccination trials in man. 


\section{SUMMARY}

The preparation of a nonpyrogenic Boivin antigen by reductive treatment with $\mathrm{LiAlH}_{4}$ is described. Infrared spectroscopic studies showed that this procedure resulted in the elimination of ester-bound fatty acid.

The chemically modified product showed virtually no toxicity when tested for lethality in mice $\left(\mathrm{LD}_{50}>1.0 \mathrm{mg}\right)$ and no pyrogenicity in rabbits $(0.1 \mathrm{mg})$; it also failed to cause leukopenia in rabbits $(5 \mu \mathrm{g})$ or intradermal inflammation in man $(0.1 \mu \mathrm{g})$.

Comparative studies showed that reduction with $\mathrm{LiAlH}_{4}$ and controlled hydrolysis with $\mathrm{LiOH}$ gave products of different chemical and biological properties. Mild alkaline hydrolysis, while virtually abolishing immunogenicity in rats, caused only moderate reduction of the pyrogenicity for rabbits and lethal toxicity for mice.

Immunization of rabbits with the detoxified material induced typical pyrogen tolerance, and immunization of mice caused the same increase of resistance to lethal challenge doses of regular endotoxin as was observed after immunization with the parent endotoxin.

The formation of precipitating antibodies after immunization of rats with various endotoxin preparations was studied by Ouchterlony's agar gel diffusion technique. The sera of rats immunized with the detoxified product produced the earliest, strongest and most completely cross-reacting precipitin bands of all of the antigens tested.

Significant protection of rats against E. coliinduced pyelonephritis was observed after immunization with the nontoxic antigen.

\section{ACKNOWLEDGMENT}

We are much indebted to Dr. D. Kodlin for his generous help in the statistical evaluation of the bioassays. The skillful technical assistance of Misses J. Siemienski and J. McConnell and Messrs. H. Douglas and P. Mueller is gratefully acknowledged.

\section{REFERENCES}

1. Webster, M. E., Sagin, J. F., Landy, M., and Johnson, A. G. Studies on the $\mathrm{O}$ antigen of Salmonella typhosa. I. Purification of the antigen. J. Immunol. 1955, 74, 455.

2. Ribi, E., Hoyer, B. H., Milner, K. C., Perrine, T. D., Larson, C. L., and Goode, G. Physical and chemi- cal analysis of endotoxin from Salmonella enteritidis. J. Immunol. 1960, 84, 32.

3. Landy, M., Johnson, A. G., Webster, M. E., and Sagin, J. F. Studies on the $O$ antigen of Salmonella typhosa. II. Immunological properties of the purified antigen. J. Immunol. 1955, 74, 466.

4. Boivin, A., Mesrobeanu, I., and Mesrobeanu, L. Extraction d'un complexe toxique et antigénique à partir du bacille d'aertrycke. C. R. Soc. Biol. (Paris) 1933, 114, 307.

5. Morgan, W. T. J., and Partridge, S. M. Studies in immunochemistry. 4. The fractionation and nature of antigenic material isolated from Bact. dysenteriae (Shiga). Biochem. J. 1940, 34, 169.

6. Hornus, G. J. P., and Grabar, P. Relations quantitatives entre l'antigène glucido-lipidique $\mathrm{O}$ et le haptène glucidique du bacille typhique et les immunsérums de lapin. Ann. Inst. Pasteur 1941, 66, 136.

7. Westphal, O. Récentes recherches sur la chimie et la biologie des endotoxines des bactéries à gram négatif. Ann. Inst. Pasteur 1960, 98, 789.

8. Westphal, O., and Lüderitz, O. Chemische Erforschung von Lipopolysacchariden gramnegativer Bakterien. Angew. Chem. 1954, 66, 407.

9. Takeda, Y., Kasai, N., Araki, M., and Odaka, T. Die Chemie des O-Antigens, seine Toxizität und Antigenität. Hoppe-Seylers Z. physiol. Chem. 1957, 307, 49.

10. Lüderitz, O., Westphal, O., Eichenberger, E., and Neter, E. Über die Komplexbildung von bakteriellen Lipopolysacchariden mit Proteinen und Lipoiden. Biochem. Z. 1958, 330, 21.

11. Noll, H. Chemistry of a toxic lipid isolated from virulent tubercle bacilli ("Cord factor") in Proc. Sixth Int. Congr. Microbiology, Rome 1953, 1, 191.

12. Noll, H., and Bloch, H. Studies on the chemistry of the cord factor of Mycobacterium tuberculosis. J. biol. Chem. 1955, 214, 251.

13. Noll, H., Bloch, H., Asselineau, J., and Lederer, E. The chemical structure of the cord factor of Mycobacterium tuberculosis. Biochim. biophys. Acta 1956, 20, 299.

14. Noll, H. The chemistry of cord factor, a toxic glycolipid of $M$. tuberculosis. Fortsch. Tuberk.Forsch. 1956, 7, 149.

15. Noll, $\mathrm{H}$. The chemistry of some native constituents of the purified wax of Mycobacterium tuberculosis. J. biol. Chem. 1957, 224, 149.

16. Noll, H., and Jackim, E. The chemistry of the native constituents of the acetone-soluble fat of $\mathrm{Myco}$ bacterium tuberculosis (Brevannes). I. Glycerides and phosphoglycolipides. J. biol. Chem. 1958, 232 , 903.

17. Braude, A. I., Carey, F. J., Sutherland, D., and Zalesky, M. Studies with radioactive endotoxin. I. The use of $\mathrm{Cr}^{51}$ to label endotoxin of Escherichia coli. J. clin. Invest. $1955,34,850$.

18. Dubois, M., Gilles, K. A., Hamilton, J. K., Rebers, P. A., and Smith, F. Colorimetric method for de- 
termination of sugars and related substances. Analyt. Chem. 1956, 28, 350.

19. Snyder, F., and Stephens, N. A simplified spectrophotometric determination of ester groups in lipids. Biochim. biophys. Acta 1959, 34, 244.

20. Tauber, H. Fatty acid ester groups in lipopolysaccharide endotoxins. Fed. Proc. 1960, 19, 245.

21. Noll, $H$. The physicochemical characterization of vitamin $\mathrm{K}$ homologues. I. Identification by a novel method of quantitative infrared spectrophotometry. J. biol. Chem. 1960, 235, 2207.

22. Braude, A. I., McConnell, J., and Douglas, H. Fever from pathogenic fungi. J. clin. Invest. 1960, $39,1266$.

23. Finney, D. J. Probit Analysis. A Statistical Treatment of the Sigmoid Response Curve. Cambridge, Cambridge Univ. Press, 1952.

24. Neter, E., Westphal, O., Lüderitz, O., Gorzynski, E. A., and Eichenberger, E. Studies of enterobacterial lipopolysaccharides. Effects of heat and chemicals on erythrocyte-modifying, antigenic, toxic and pyrogenic properties. J. Immunol. 1956, $76,377$.

25. Ouchterlony, O. In vitro method for testing toxinproducing capacity of diphtheria bacteria. Acta path. microbiol. scand. 1948, 25, 186.

26. Halbert, S. P., Swick, L., and Sonn, C. The use of precipitin analysis in agar for the study of human streptococcal infections. II. Ouchterlony and Oakley technics. J. exp. Med. 1955, 101, 557.

27. Braude, A. I., Shapiro, A. P., and Siemienski, J. Hematogenous pyelonephritis in rats. I. Its pathogenesis when produced by a simple new method. J. clin. Invest. 1955, 34, 1489.

28. Fromme, I., Lüderitz, O., Nowotny, A., and Westphal, O. Chemische Analyse des Lipopolysaccharids aus Salmonella abortus equi. Pharm. Acta Helv. 1958, 33, 391.

29. Westphal, O., Lüderitz, O., Eichenberger, E., and Keiderling, W. Über bakterielle Reizstoffe. I. Reindarstellung eines Polysaccarid-Pyrogens aus Bacterium coli. Z. Naturforsch. 1952, 7b, 536.

30. Biological Applications of Infrared Spectroscopy. Ann. N. Y. Acad. Sci. 1957, vol. 69, Art. 1.

31. Rosen, H. A modified ninhydrin colorimetric analysis for amino acids. Arch. Biochem. 1957, 67, 10.

32. Braude, A. I. Mechanism of action of a toxic bacterial antigen. Trans. Amer. Acad. Ophthal. Otolaryng. 1959, 63, 634.

33. Brown, W. G. Reductions by lithium aluminum hydride in Organic Reactions, R. Adams, Ed. New York, Wiley, 1951, vol. 6, p. 469.
34. Reed, L. J., and Muench, H. A simple method of estimating fifty per cent endpoints. Amer. J. Hyg. 1938, 27, 493.

35. Adler, F. L. Competition of antigens in Mechanisms of Hypersensitivity, J. H. Shaffer, Ed. Boston, Little, Brown, 1959, p. 539.

36. Jerne, N. K. Immunological speculations. Ann. Rev. Microbiol. 1960, 14, 341.

37. Noll, H., and Youngner, J. S. Virus-lipid interacactions. II. The mechanisms of adsorption of lipophilic viruses to water-insoluble polar lipids. Virology 1959, 8, 319.

38. Braude, A. I., Shapiro, A. P., and Siemienski, J. Hematogenous pyelonephritis in rats. III. Relationship of bacterial species to the pathogenesis of acute pyelonephritis. J. Bact. 1959, 77, 270.

39. Braude, A. I., and Siemienski, J. The influence of endotoxin on resistance to infection. Bull. N. Y. Acad. Med. 1961, 37, 448.

40. Finney, D. J. Statistical Method in Biological Assay. New York, Hafner, 1952, p. 589.

41. Johnson, R. B. An immunogenic antigen of low toxicity derived from Shigella sonnei. J. Immunol. 1955, 74, 286.

42. Nowotny, A. Chemical structure of a phosphomucolipid and its occurrence in some strains of Salmonella. J. Amer. chem. Soc. 1961, 83, 501.

43. Schenker, E. Neuere Methoden der präparativen organischen Chemie. IV. Anwendung von komplexen Borhydriden und von Diboran in der organischen Chemie. Angew. Chem. 1961, 73, 81.

44. Landsteiner, $K$. The specificity of serological reactions. Cambridge, Mass., Harvard Univ. Press, 1945 , p. 43.

45. Staub, A. M. Bases chimiques de la spécificité immunologique des antigènes des Salmonella. Ann. Inst. Pasteur 1960, 98, 814.

46. Freedman, H. H. Further studies on passive transfer of tolerance to pyrogenicity of bacterial endotoxin. The febrile and leucopenic responses. J. exp. Med. 1960, 112, 619.

47. Braude, A. I., McConnell, J., and Douglas, H. The behavior of $E$. coli endotoxin (somatic antigen) during infectious arthritis. In preparation.

48. Landy, M. Enhancement of the immunogenicity of typhoid vaccine by retention of the $V_{1}$ antigen. Amer. J. Hyg. 1953, 58, 148.

49. Lüderitz, O., Westphal, O., Staub, A. M., and Le Minor, L. Preparation and immunological properties of an artificial antigen with colitose (3-deoxy-L-fucose) as the determinant group. Nature (Lond.) 1960, 188, 556. 